\title{
Optimization of the Educational Process at the Department of Otorhinolaryngology of IFNMU Considering the Competency-Based Approach
}

\author{
Diana Orishchak*, Vasyl Popovych, Nataliia Vasyliuk, Ivanna Koshel, Ostap Orishchak
}

\begin{abstract}
The paper presents modern competency-based approach to teaching otorhinolaryngology using new technologies that will improve the assimilation of new material considering each student' knowledge, skills, and experience. The competency-based approach can be successfully implemented based on active learning, introducing elements of professional activity in the educational process. While analyzing clinical cases, business and learning games, the student becomes a specialist and future's team member. The quality of education should be improved through an effective organization and informatization of the educational process, the introduction of the latest research results in teaching practice, the provision of high-quality teaching and the development of modern learning and teaching base.
\end{abstract}

Keywords

otorhinolaryngology; teaching; competency; new technologies

Ivano-Frankivsk National Medical University, Ukraine

${ }^{*}$ Corresponding author: diana-lor@i.ua

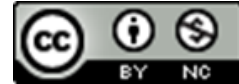

Copyright @Diana Orishchak, Vasyl Popovych, Nataliia Vasyliuk, Ivanna Koshel, Ostap Orishchak, 2020

The concept of competence serves as a basis of state educational standards of higher education.

Competence is the set of competencies, namely knowledge, skills, abilities, and experience essential for effective activity in a certain field. The concept of competence includes cognitive and operational technology components, as well as motivational, ethical, social, and behavioral ones [4]. The competency-based approach focuses on students' mastering new knowledge as a whole rather than mastering knowledge and abilities that are separated from each other. The competency of medical students is of a certain structure; its components are associated with the doctors' ability to solve different professional problems including making diagnosis, prescribing treatment, and coping with problems the patients experience in everyday life considering the pathology. The skills of self-education, critical thinking, independent work, self-organization and self-control, teamwork, the ability to predict the outcomes of different possible choices, to infer cause-effect relationships, and to resolve problems are among such knowledge [2, 4].

At the present stage of dynamic development of medical expert systems alongside with the introduction of the latest therapeutic and diagnostic methods, higher medical education, being a key component of healthcare reform, should provide high-quality training of students and young doctors $[1,3,4,5]$.

The quality of education should be improved through an effective organization and informatization of the educational process, the introduction of the latest research results in teaching practice, the provision of high-quality teaching and the develop- 


\section{Optimization of the Educational Process at the Department of Otorhinolaryngology of IFNMU \\ Considering the Competency-Based Approach — 2/4}

ment of modern learning and teaching base $[1,2,3]$.

Practical training provides for a sufficient number of classrooms with the workplaces equipped for examination. The use of videoconferencing to share the content between the classroom and the operating unit, thereby demonstrating surgical interventions, as well as the management of patients under supervision of a teaching physician when students become visually acquainted with typical clinical manifestations of the disease, significantly improve the quality of teaching.

The Department of Otorhinolaryngology of IFNMU trains the fourth-year medical and dental students, as well as students studying at the Faculty of Foreign Citizen Training. The curriculum includes 90 term hours or 3 credits, namely 4 hours of lectures, 36 hours of practical classes and 50 hours for independent extracurricular activity. The formation of the experience in independent searching for new knowledge is the most important ability every student needs to develop. The students work out the material independently at home, and, to save class time, they solve on-line tests available on the university's website to assess their baseline knowledge. The teacher checks the results before the lesson, or students report their results at the beginning of every lesson. The formative assessment is carried out by the teacher during practical lesson where students are asked, clinical cases are discussed, practical skills are mastered. To implement training, we use case studies and virtual reality tasks depicting the pathological process when students should describe changes they identified by themselves. Attention is paid to both correct diagnosis, prescription of adequate treatment and examination algorithm.

Great attention is paid to the mastery of practical skills by performing them on each other. They include ENT examination, namely nose examination (anterior, posterior rhinoscopy, nasal breathing test, olfactometry, analysis of X-ray images, computed tomography scans); ear examination (otoscopy, hearing screening, camertonal tests, analysis of audiograms); pharynx examination (pharyngoscopy); laryngeal examination (indirect laryngoscopy); role-playing games when students are asked to act as a patient (formulates complaints), a physician (collects medical history, examines the patient and prescribes screening methods, treatment) and an expert consultant (evaluates the correctness of physician's decisions).

To master the skills needed for ENT examination, performing anterior and posterior nasal packing, laryngeal injection, students use mannequins as well. The banks of X-ray images, computed tomography scans and audiograms are available at every subdivision of the Department.

In the dressing rooms, students together with their teacher carry out manipulations to the patients of clinic (ear irrigation, ear clearing, hearing test, $\mathrm{X}$-ray inspection, audiometry).

Communication with patients forms the proper approach to the patient, the ability to ask probing questions and specify complaints. Writing and defending the case history are the result of mastering all the necessary skills by students. Since there are patients who do not give their consent to be examined by students, digital ENT examination is used at the department. The teacher examines the patient by means of miniature digital endoscope connected to Android device that allows visualizing the organ being examined. Each student is able to watch the procedure on the teacher's phone or on personal phone using a Wi-Fi or Bluetooth connection (Fig. 1).

The final assessment of knowledge acquisition is the final modular control that consists of tests, demonstration of practical skills and oral questioning including 4 questions within different discipline branches. In addition to the overall score (obtained for academic activity and the final modular control), students can earn additional scores for independent work, namely participation in the student's scientific conference, the award-winning places in medical competitions, reports, or presentations.

The primary role of the teacher during practical session is to provide an effective feedback process between teachers and students, as well as to manage students' learning motivation.

The competency-based approach can be successfully implemented based on active learning, introducing elements of professional activity in the educational process. While analyzing clinical cases, 


\section{Optimization of the Educational Process at the Department of Otorhinolaryngology of IFNMU}

Considering the Competency-Based Approach - 3/4

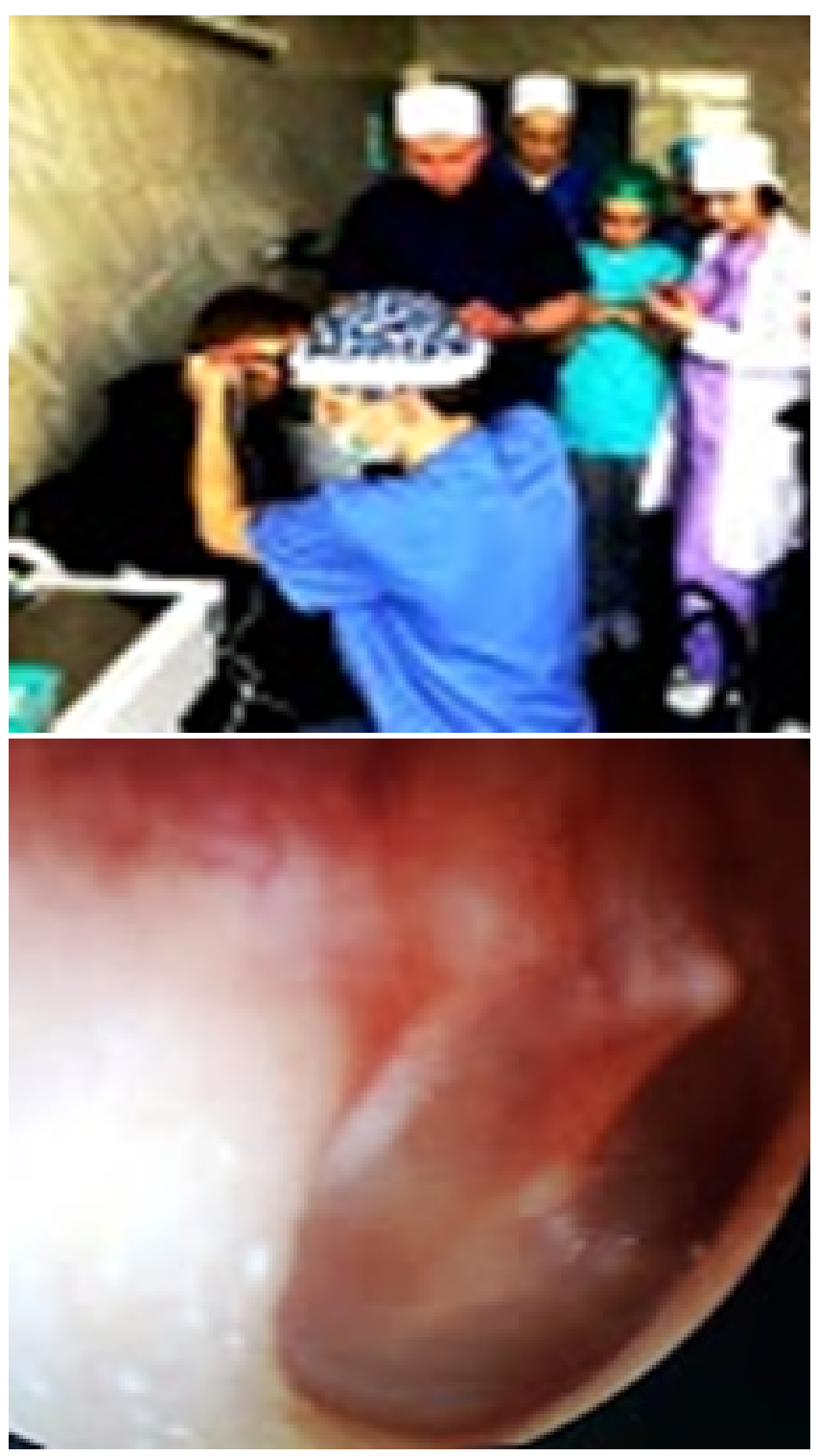

Figure 1. Examination and clinical discussion of a patient during practical lesson "External and middle ear diseases", digital otoscopy .

business and learning games, the student becomes a specialist and future's team member. In this case, the teacher's personality, namely his/her ability to create positive motivation to discipline learning, being a role model for students, is of great importance. Thus, the competency-based approach to teaching otorhinolaryngology may be formed on the basis of developing the abilities to understand, assimilate, analyze and perform.

\section{Conclusions}

1. The introduction of modern teaching methods at the Department of Otorhinolaryngology of IFNMU allows future doctors to develop the competency-based approach to the diagnosis and treatment, as well as their creative abilities.

2. The use of digital technologies during patient demonstration and ENT examination allows each student to see, describe and draw conclusions about certain pathology.

3. The role of the teacher in introduction of innovative technologies when studying otorhinolaryngology is to choose teaching technologies correctly, to provide methodological support and assistance to students at different levels of task complexity, and to create a positive learning environment in the classroom.

\section{Conflict of Interest}

The authors stated no conflict of interest.

\section{Financial Disclosure}

The authors declared no financial support.

\section{References}

[1] Bakirova RE, Nursultanova SD, Muravleva LE et al. Innovative technologies in training of students of medicine. Modern problems of science and education. 2018; (3): 101-108. [published in Russian]

[2] Maksymenko SD, Filonenko MM. Pedahohika vyshchoii medychnoii osvity. Kyiv: Tsentr uchbovoii literatury. 2014; 288p.

[3] Stepko M. Svitovi tendentsii rozvytku system vyshchoii osvity ta problemy zabezpechennia yakosti i efektyvnosti vyshchoii osvity v Ukraiini. Vyshcha shkola. 2013; 7: 13-22.

[4] Filonenko MM. Metodyka vykladannia u vyshchii medychnii shkoli na zasadakh kompetentnisnoho pidkhodu: Metodychni rekomendatsii dlia vykladachiv ta zdobuvachiv naukovoho 
stupeniu doktora filosofii Ukraiiny. Kyiv: Tsentr uchbovoii literatury. 2016; 88p.

[5] Shukhtin V, Shukhtina I. Innovatsini metody vykladannia studentam medychnykh fakultetiv. Novyi Kolehium. 2015; 2: 51-54.

Received: $2020-05-23$

Revised: 2020-06-17

Accepted: $2020-06-17$ 